\title{
Outsourcing and "dismantling" of steady jobs at hospitals*
}

\author{
A terceirização e o "desmonte" do emprego estável em hospitais \\ La tercerización y el "desmonte" del empleo estable en hospitales
}

\author{
Helton Saragor de Souza ${ }^{1}$, Áquilas Nogueira Mendes ${ }^{1,2}$
}

How to cite this article:

Souza HS, Mendes AN. Outsourcing and “dismantling" of steady jobs at hospitals. Rev Esc Enferm USP. 2016;50(2):284-291. DOI: http://dx.doi.org/10.1590/ S0080-623420160000200015

\author{
* Extracted from the dissertation: "A interpretação \\ do trabalho em enfermagem no capitalismo \\ financeirizado: um estudo na perspectiva teórica \\ do fluxo tensionado". Universidade de São \\ Paulo, Faculdade de Saúde Pública, 2015. \\ ${ }^{1}$ Universidade de São Paulo, Faculdade de \\ Saúde Pública, São Paulo, SP, Brazil. \\ 2 Pontifícia Universidade Católica \\ de São Paulo, Departamento de \\ Economia, São Paulo, SP, Brazil.
}

\section{ABSTRACT}

Objective: To relate hospitals' organizational structure as the core of a web of outsourced services and flexible employment bonds among healthcare professionals in the context of finance capitalism, analyzing work arrangements based mainly on the type of employment bond. Method: Qualitative research through ethnography, interviews, data analysis, and case studies. The case studies were concentrated in 3 hospitals located in the São Paulo metropolitan region under different management types: public administration; outsourced administration via a healthcare social organization (HSO); and private administration. Results: This study highlights a trend in outsourcing, dismantling of steady jobs, and shaping working relations asymmetrically in terms of healthcare professions. Conclusion: These aspects are characteristic of contemporary capitalism and post-Fordist work organization. In this context, the state under sponsorship cripples the very existence of an effective human resources policy, creating a favorable environment for outsourcing and flexibility of employment bonds among healthcare workers.

\section{DESCRIPTORS}

Capitalism; Labor Force; Employment; Outsourced Services; Health Personnel; Personnel, Hospital. 


\section{INTRODUCTION}

The discussion of the insertion in the work market is not a recent subject in the field of the collective health and health professions. Moreover, work in healthcare was addressed under this perspective in an unprecedented way by Donnangelo in her renowned book Medicina e Sociedade: 0 médico e seu mercado de trabalbo ${ }^{(1)}$. However, starting in the 1990s, one can observe a trend in hospital services of partial or total outsourcing through an instrument that transferred the management of public entities to private law social organizations $^{(2-3)}$, with significant consequences on healthcare professionals' daily lives, especially in the areas of nursing, due to the fact they account for the majority of professionals at hospitals. This is paramount regarding the reality of human resources in this segment ${ }^{(4)}$. This article shows how hospital services organize according to the "core-periphery" structure $^{(5)}$, associated with dismantling steady jobs. It also points out various elements of economic policy and national legislation $^{(6-7)}$ that has shaped the favorable context for this erosion of employment contracts.

Analyzing employment bonds is imperative to understand the shaping of healthcare professionals' working arrangements ${ }^{(8-9)}$. From this perspective, various aspects of daily life have the contract type as a foundation, such as power at the workplace, autonomy, the domestic work market (promotions, moves, resignation), remuneration, class actions, etc. ${ }^{(10-12)}$. In the authors' opinion, issues related to healthcare professionals' outsourcing and flexibility of employment bonds must be part of the agenda that deals with the reality of the Unified Health System (SUS, as per its acronym in Portuguese) in contemporary capitalism, under financial capital's dominance ${ }^{(13-15)}$.

The universal right to healthcare included in the 1988 Brazilian constitution was constrained by underbudgeting over the past 27 years - precisely those years when financial capital (interest-bearing capital, according to Marx) ${ }^{(16)}$, especially in its more perverse form of fictitious capital was sovereign among the different types of capital, industrial and commercial. Among other effects, its action has been hurting government budgets, which compromises the maintenance of rights related to the so-called welfare state or the realization of new rights in countries that have been lagging in this process, like Brazil ${ }^{(17)}$.

The presence of fictitious capital cannot be seen as lack of controls or distortion; on the contrary, it is part of capital's relentless self-valuing process - in the context of industrial capital's retreat - regardless of being fictitious, not producing any added value, and functioning in a speculative way $^{(15-17)}$. As Marx argues in the third book of Capital ${ }^{(16)}$, it is the most fetishist form of capital: money that makes money, without going through production.

Actually, the foundation of the capitalist structural crisis lies on the existence of two main trends that have been articulated, especially from the late 1960s: the trend of a decline in the profit rate of the capitalist economies and the response to this trend, i.e., financial capital hypertrophy, specifically fictitious capital, which began to lead the dynamics of capitalism in that period and became central in the world's economic and social relations, particularly from $1980^{(15-17)}$.

From the viewpoint of work organization, one can observe a relative exhaustion of Fordism as a vehicle for capital accumulation. This was evident in the mid-1970s in the United States and in some European countries, and it was answered differently by capital as an attempt to recover its profitability or yield. These changes have been widely called productive restructuring, Toyotism (Ohnoism), or post-Fordism and have significantly changed the production of goods and the economic activity service rendering.

The goal of these changes was to fight the trend of profit drops and consisted of the "just-in-time" method (reducing supplies and connecting production to market demands); flexibility of work relations; quality control circles; outsourcing; and subcontracting. As a consequence for the work market, there was an increase in long-term unemployment and both part-time and temporary work, without the rights that existed in the previous period in central capitalist countries. The new jobs focused on rendering services.

In healthcare services, one does not necessarily identify the just-in-time method that is typical of plants or transportation services, where concern with the movement of materials and information is the center of rationalization. However, the idea of flow is vital in the work process. Care for patients is organized this way precisely because of the demand reactivity, and flow determines the way to work and disciplines workers.

Just-in-time is an additional application, rather than the principle of flux tendu. The just-in-time paradigm ${ }^{(5)}$ is shown in the vast majority of manufacturing activities and in services as well, such as fast-food chains, supermarkets, and hospital units, specifically. There is a combination in the workplace of disproportionate demand and professionals' working conditions, mainly because of the high number of patients seen by few workers. Additionally, the lack of materials at times intensifies the work and overload, because there is an obligation to service everyone and reach the hospital's goals, even without the minimal conditions to do so. This logic also conditions the work market; consequently, there is a trend toward temporary and weak employment bonds.

The direct effects of the contemporary capitalist crisis on Brazilian public healthcare occurred basically by means of capital's appropriation of public funds in the pursuit of its self-valuing ${ }^{(17)}$. This movement from capital in the past 35 years coincides with the establishment of the SUS ${ }^{(14-15)}$. Different strategies were prioritized to recover the profit rate through various mechanisms to reduce social rights, especially maintaining the underbudgeting of public healthcare and ensuring intensified outsourcing and poor working conditions in healthcare through weakened contractual employment bonds for healthcare workers and poor-quality service for users.

Two relevant phenomena can be highlighted for the purpose of this study: the expansion of capital into service-rendering areas to accomplish its value, for instance, healthcare services; and the appropriation of the state budget through the public debt instrument ${ }^{(15-17)}$. This way, 
healthcare services in the context of the dynamics of capital valuing, under financial dominance and healthcare underbudgeting from the state, creates a private healthcare service sector willing to force the workforce price. In terms of public services, it hinders the development of an effective human resources policy by the state.

These aspects are represented by continuing restraining macroeconomic policies adopted by the federal government since the Fernando Henrique Cardoso administration. They created constant hindrances to the full development of comprehensive health care in the country, given the underbudgeting situation they imposed on the Unified Health System (SUS). Federal governments have been strictly sticking to their role subordinate to financial capital, adopting an economic policy based on the tripod of inflation targeting, primary surplus, and a floating exchange rate, producing cuts in public expenses and prioritizing the payment of interest and public debt amortization, and yet keeping various mechanisms to transfer government funds to the healthcare private sector. Ultimately, such policies have resulted in strong cuts to social rights policy expenditures, with insufficient and unsafe sums for public healthcare.

Moreover, it is reasonable to add that mainly after the early 1990s, public resources have been fought over with financial capital that leads the capital's movement and whose interest is maintained by the payment of public debt interests and access to resources that used to be out of its reach. It is not possible to leave the national legislation out of this picture, which paved the way for the institutional unfeasibility of an effective human resources policy for the public healthcare system. For instance, there is the fiscal responsibility law, which set limits on the increase in expenses for personnel also in the healthcare area, and the transfer of public hospitals to social organizations as stipulated by the Brazilian state managerial reform, with an increasing transfer of public resources to these institutions.

This article's objective is to analyze hospitals' organizational structure and their type of contractual bond for healthcare professionals as pivotal for the configuration of the work system at the studied units in the scope of contemporary financial capitalism. The analysis will be developed from three perspectives. The first one addresses hospitals as cores of a subcontracted services net. The second discusses the work system at hospitals and the central importance of employment bonds. The third discusses the trend of "dismantling" steady jobs.

The premise this study is based on is that it will help understand daily aspects of work in healthcare, particularly nursing practice in recent times. It is understood that such a discussion enables a comparison between core issues in healthcare services and the necessary theoretical production, thus ensuring an advance for scientific knowledge in this field, founded upon concrete reality.

\section{METHOD}

For the analysis of the flexibility of contractual bonds among healthcare professionals, case studies were used. These cases were concentrated in three hospitals located in the São Paulo metropolitan region under different management types: public administration; outsourced administration via a Healthcare Social Organization (HSO); and private administration. It is important to recognize that the results of this research are confined to the reality of these hospitals, and generalizing them is not reasonable. All of them are general hospitals that do not encompass teaching activities and are located in central regions in their cities. Additionally, they all deal with similar outpatient and hospital activities, from low and average outpatient complexity to high hospital complexity. Only the hospital managed by a Social Organization described its activities as average in complexity for the outpatient scope.

The means of research consisted of ethnographic techniques and semi-structured interviews, whose script encompassed work comprehensiveness aspects such as educational background, professional history and perspective, the situation of the work market, remuneration, professional qualification, the work process, relationships with technology, aspects of outsourcing, conflicts in the workplace, the domestic work market, class action, subjectivity at work, and workers' health. Measuring professionals' type of employment bond used the National Registry of Health Establishments (CNES, as per its acronym in Portuguese) as a database.

This study was conducted in first semester of 2014 and compared the realities of the studied units. The ethnographic survey was based on extended case studies ${ }^{(18)} \mathrm{com}^{-}$ posed of ethnography that nurtured connections between micro and macro aspects by reconstructing social theory ${ }^{(19)}$. These ethnographic techniques used to grasp data from reality are important elements to create a dialectic analysis, correlating the results and social entirety, a fundamental guideline to this study that is supported by historical and dialectic materialism.

As a guideline for ethical parameters, we used Resolution no. 466 of December 12, 2012, from the Brazilian National Health Council for research, from the first contact with the interviewed individual to the publication of the research results, in agreement with consolidated opinion no. 766,156 of the Committee of Ethics in Research of the Faculdade de Saúde Pública of Universidade de São Paulo in 2014. At these units, assistants, specialists, and nurses were the subjects of this study. Professionals with both a university degree and an associate degree were interviewed at each one of the studied hospitals.

\section{RESULTS}

\section{Structure Of THe STUdied hospitals}

In spite of differences in clientele and institutional goals, all of the hospitals are managed based on the organizational principle of decompartmentalizing and outsourcing ${ }^{(20)}$ of their activities, or else constitution of a network-hospital in the three forms of management. Before the 1990s, the hospital units all had their own sections and divisions in their entire functioning, according to accounts by interviewed 
professionals. Currently, various functions (both core functions and others) are outsourced to various subcontractors, such as particular medical specialties, like pediatrics at the public hospital, and exam sectors of examinations and support activities, such as the radiology section, the blood bank, the pathology laboratory, cleaning, the kitchen, and others. This change is clear at the hospitals (public and outsourced ones). The private hospital was established in the 2000s; thus, it was formed based on the principal of subcontracting. Nevertheless, this process became stronger. For example, the reception sector was outsourced during this study.

The nurse (quality manager) of the private hospital describes this trend as follows:

Here, almost everything was outsourced. Nursing is not outsourced because it is not allowed, because it is the activity and means. It is the only sector that cannot be outsourced; all the customer service has been outsourced (...). Doctors are freelancers, they are not CLT in any hospitals; they are freelance professionals, but you see that at most hospitals, not just here. All the hospitals are changing to outsourcing, because today it's very difficult for people to survive in our country with this enormous tax burden. (...) Pharmacy, Speech pathology, Physical therapy, Nutrition, Customer service, Security, Cleaning.

Based on this statement, it is clear that nursing cannot be outsourced because it constitutes an end activity. In summary, the definition of the activity and mean is that it is not the main activity to achieve the organization's objective (both companies and public agencies), even though they may be fundamental for the achievement of the primary objectives. In contrast, the end activity concerns the organization's objective and central activity. In this particular case, healthcare occupations are considered the main activities at hospital units; however, "frauds" on the employers' part are common and they subcontract healthcare professionals. This is the main issue to be modified by Draft Bill no. 4330/2014, which proposes unrestricted outsourcing of labor activities ${ }^{(21)}$.

The core and periphery dynamics can be inferred from the account. When considering hospitals as the core of a network, it is possible to observe that the situation of outsourced workers is usually poorer and more unstable in relation to the steady employees of the hospital core. Outsourced workers are submitted to pressure from competition among service vendors that is made to employees of subcontracted companies. An example of such pressure is an episode that took place in the public hospital, where a particular radiology company delayed wages for three months and workers continued to work, because if they showed any unrest, the company they were connected with would cease to provide services; consequently, they would lose their jobs. The answers regarding this matter were contradictory. The company owners held the city administration accountable for delaying payments. On the other end, the hospital board said the company was not fulfilling its contractual obligations. The outcome was that the hospital board ended its contract with this vendor.

In the radiology sector, there is a case that took place at the private hospital. Some years ago, the owners outsourced the sector. The owner of the subcontracted company was the former employee of another hospital that disconnected from the regular system guided by the Labor Law Consolidation (CLT, as per its acronym in Portuguese). Therefore, the specialist had a representing office as a legal firm. At first, this worker considered that to be a good opportunity; over time, though, he realized that his income did not increase proportionally to the worked hours and that he no longer had labor rights. The limit stated by the legislation established a 24-hour week for his category ${ }^{(22)}$. Because he was outsourced, the specialist worked 60 hours per week at the private hospital. Recently, due to union mobilization, that sector reverted its outsourcing, contrary to the trend of increasing outsourcing.

According to the managers of the three hospitals, not only is outsourcing necessary but it is also essential. In their opinion, the economy and the problems transferred to third parties make up for the recurring problems contractors have with their subcontractors. Contradictorily, both managers and professionals of the three hospitals criticized the quality of subcontracted services ${ }^{(20)}$, for instance, delays in delivering results of exams made by outsourced laboratories were identical in the three outsourced units. We highlight the account by a public hospital nurse of the quality of the outsourced catering services:

So, one thing that shocks me a little is that the professionals here cannot have dinner because there is no food left (...). There are problems with patients because the waitresses don't leave the food there. It's for all the patients; you have to place a diet order by 8:00. If you don't do it by 8:00, it's just tea and cookies. Then I tell you: a patient has tuberculosis and needs to eat balanced food (...) He didn't have lunch and when the night comes, he won't have dinner...

\section{HeAlthCARE PROFESSIONAlS ${ }^{\prime}$ EMPLOYMENT bONDS}

According to CNES data, approximately $90 \%$ of the doctors at the public hospital had temporary contracts due to "urgency". Regarding nursing categories, approximately $54 \%$ of employees were hired by a stated period by the same hospital. At the outsourced and private hospital, the nursing categories are hired by CLT contract. Temporary contracts are expanding into other healthcare professions.

Therefore, it was possible to identify direct outsourcing among professionals at the studied hospitals, particularly at the private hospital. For example, both doctors and physiotherapists were subcontracted by a particular company and were "freelancers" at the subcontracted company, and not freelancers at the hospital. Although the most common practice is the flexibility of bonds through direct corporate contract of nutritionists, occupational therapists, speech pathologists, and psychologists at the private hospital, at the hospital managed by a Social Organization it was not possible to find the corporate contract trick. Nonetheless, professionals with more than one contractual bond claim that this behavior exists at other hospitals managed by Social Organizations. It is important to clarify that the term "corporate contract" or "corporate contracting" refers to the 
practice of hiring workers through formal adjustments that give them the appearance of a company. Most of the time, they are contracted for service rendering. This practice is a trick in the employment contract and the rights established by the CLT. In our approach, this refers to the worker's situation as an ordinary employee, without access to labor rights, mainly greater stability of an employment bond.

Regarding nursing categories, the bibliography points to the existence of an outsourcing trend in the segment inasmuch as the diagnosis and specialized therapeutic units are outsourced $^{(23)}$. In other words, specialized diagnostic exam units are outsourced (network) in relation to the hospital (core). As a consequence, nursing professionals at these units suffer consequences from this model; however, in the three case studies, this form of outsourcing was not found. For instance, none of the hospitals outsources the contract and the employment of their professional body at the hospital under the subcontracted company's direction; however, to the extent where outsourcing is a trend of post-Fordist organizations in service rendering relations, the outsourcing of specialized subservices is common.

In the interview with the nurse in the private hospital, she mentions a contemporary mechanism to make employment bonds of nursing categories less secure from the employer's point of view. She says:

Regarding these customer service and cleaning professionals, I don't have much difficulty with the fact that they're outsourced, to be honest, but when I was a nursing manager (...), we worked with cooperatives of assistants, specialists, and nurses. For the first months they were part of the cooperative; after that time they were hired by the company. When I became a manager it was hard because those cooperative employees didn't have any responsibility to me because they were paid per day (...) they started out as cooperative workers and after three months we could even renew it for one more (month). After three or six months they would be our CLT. Then I see that cooperative workers, because they earn per day - and if they get another job they will be CLT - they have no commitment to you. Now, in these other areas, things are so widespread that people already (accept that situation).

Later, other workers told us about the attempt by hospital owners to expand the number of cooperative workers in their staff. They wouldn't hire some of the workers after the temporary period. This attempt did not succeed because when workers realized that "maneuver", they preferred other hospitals with the guarantee from the start of being hired.

Evidently, this dynamic shapes professionals' daily work. At visits to the private unit, the authors observed rugged working relations, such as the layoff of the interviewed assistant nurse for being considered an uncooperative worker. He actually had employment stability for being a member of the Accident Prevention Commission. The assistant was rehired after a successful legal challenge. In our interpretation, decisions about relocation, promotions, and bonuses are made entirely by the company. All of the interviewees who were at units with CLT bonds said that these requirements were defined by the board, both at the private hospital and at the outsourced one.
Delving deeper into this type of work relation, it was possible to identify a need for greater consent by statutory employees at the public hospital. The authors were told at the hospital visits that an old nurse committed moral harassment. There was a clash with workers and the union, resulting in this professional's removal from her leading position. This fact shows that establishing a despotic relationship is not possible due to the work system and the balance of forces between workers and the hospital administration. Likewise, a workers' strike took place at the public hospital for reasons of wages and working conditions in recent years. Such an episode is unimaginable for workers at hospitals managed by a Social Organization and on a for-profit basis.

\section{DISCUSSION}

\section{HOSPITALS AS CORES OF A SUBCONTRACTED SERVICES NETWORK}

At the hospitals, it was possible to identify an organization similar to the firm-network integration found in other economic sectors. This networking integration includes decompartmentalizing activities and a hierarchy in the services network, outsourcing their activities or subdividing services under the responsibility of contracted companies in the same space. The pressure on the knots of this net relates to the internal organization where each worker is equal to a "company" and has to offer services at the right moment to supply the employer's or contractor's needs. The situation of professionals who are hired as a legal entity, being equal to "companies," or those who are hired temporarily, follows a cost reduction and work intensification logic ${ }^{(5,24)}$. Consequently, a "customer-supplier" relationship is established in daily work as a form of just-in-time.

The result of this process in healthcare services is a significant reduction of statutory or CLT employees coexisting more and more with companies and workers "rendering" supporting services, which are often vital services for the unit functioning. About this characteristic, the hospital as a core of a network submits sectors and workers, pressuring them to perform some tasks and services in a very short period of time. The idea of competition is built from the idea that a subcontractor company or a professional without employment bonds can easily be replaced at any time in case the contractor is not happy. This setting is a premise for reducing time in the work process. In other words, workers at the periphery of the network have a more intense work pace because they live with insecurity, instability, and often reduced labor rights. These aspects of a "network company"(5) perfectly fit the analysis of the studied hospitals.

Although outsourcing is a general trend, it affects professional sectors with different intensities. The use of cooperatives for specialists has a greater influence on workers' lack of security when compared with the outsourcing of professionals such as pediatricians at public hospitals through a doctors cooperative because of the qualification aspect. There is also a gradation between the outsourcing of a sector within the facility and outsourcing of this sector as a specialized job ${ }^{(23)}$. The effect of outsourcing on 
other categories of healthcare workers is more serious in the first case, especially in terms of pressure on people's daily work.

In the examples mentioned of "cooperatives," corporate contracting, and "perpetual" temporary workers, we foresee that these employer measures will characterize a more serious situation during periods when job offers are scarce for some occupations, such as nursing, for example, or when the national labor law changes.

\section{THE TREND OF "DISMANTLING" THE STEADY JOB}

Like with other productive sectors in the worldwide economy ${ }^{(9)}$, we point out the dismantling of the permanent, steady job as a trend for healthcare professionals ${ }^{(25)}$, although it is not clear what the most common instruments for this employment flexibility are (cooperative, part-time and temporary work, contract by employment agency or agency labor, temporary contract for projects and programs, corporate contracting, etc.). One must also consider the interrelation of these forms of hiring professionals. This instability does not refer exclusively to wages but also to other benefits and rights (material support, interpreted as material conditions of subsistence for reproduction of the work force). Thus, flexibility is the general trend.

The type of employment bond is decisive in the contrasts of labor relations and the functioning of the studied hospital units. The difference in employment bonds is the most important aspect for workers concerning management types. In summary, public workers fall into the category of statutory systems. Permanent positions are granted more rights in comparison to the CLT regime or temporary workers, such as, for instance, the amount of sick days, bonus leave for attendance, and above all, stability according to which punishment or termination may occur only after an administrative disciplinary procedure where workers have a solid right of legal defense.

When direct administration was replaced by management by Social Organizations, the hospitals contracted new employees without any labor bond under the public administration statutory system (even though a substantial portion of public hospitals already used temporary contracts). Their employment bond was established under the work system guided by CLT, which differs from the statutory system in terms of hiring, termination, and rights. The CLT system does not encompass stability as a statutory position.

In addition to the change in employment bond, the nursing assistant at the hospital managed by a Social Organization told us about recurring delays in payment and about payments after pressure from the union. At the time, the professional was very conscious of speaking in a low voice so that other people would not hear her. Labor rights under the CLT regime were also applied poorly.

In the public sector, the termination of permanent employees cannot be automatically justified by some kind of incompetence. In the private sector, the possibility of termination and resulting instability produces intensification of work because workers submit more strongly when motivated by fear. In interviews and visits to hospitals we have seen turnover as a characteristic of the CLT employment bond, both at the outsourced unit and the private hospital, although it was also mentioned at the public hospital, mainly by temporary workers.

Regarding medical professionals, Donnangelo ${ }^{(1)}$ shows a heterogeneous entry into the work market, oscillating between the poles of waging and autonomy through business or autonomous labor exercise. From this heterogeneity, the author diagnoses the trend of loss of medical work autonomy in the context of the 1970s. This reflection proves current when considering observations from the studied cases, in which this heterogeneity becomes broader. Additionally, there is the common practice by employers in the private sector of corporate contracting or temporary contracts, for example, which are most commonly used at the public hospital studied.

In the literature on nursing work, there is a trend of flexible work arrangements ${ }^{(26)}$ and temporary contracts for projects or government programs. This trend is stressed by the shortage of public examinations in particular segments, and many skilled professionals with employment bonds complement their income with poor double bonds.

From an empirical analysis, it was possible to infer that the hospital structure as the core of a network of outsourcing activities, as well as the flexibility of contractual bonds, occurs in various combinations; however, they express a tendency to dismantle stable employment and constitute a situation in which professionals work as salaried employees but are not granted the corresponding rights.

Based on these examples, one should reflect on the impasses of employment in healthcare, inasmuch the years following the implementation of SUS became known as the "human resources anti-policies period"(27), causing many problems for work management. Specifically in terms of the quality of subcontracted services and working conditions, this context shows its evils but remains sharply defended in the name of resource saving and profitability. From the point of view of service management, there is the problem of continuity and forming teams once the shortness of employment bonds hinders the stability needed for professional involvement and development, with consequences on workers' lives, including the most qualified ones.

Although the scope of this study is the Brazilian national reality in the realm of hospitals located in metropolitan areas, we believe that the phenomenon includes capital's globalized effect on employment in health care. Although the goal of this study is not to synthesize the multiple singularities of the international context, the international literature includes approaches of this new type of flexible employment with varied theoretical and political positions.

In the United States, specifically in New York State, the predominance of low-wage jobs and low educational levels in the projection of the healthcare workforce is diagnosed as a result of economic pressure on the healthcare industry to use the workforce more efficiently and effectively ${ }^{(28)}$. In Canada, an article discussed the growing presence of temporary employment agencies in the context of job scarcity and how professionals are dissatisfied with this form of employment ${ }^{(29)}$. In France, we located a publication on 
unemployment and poor working conditions in a survey conducted by the national federation of nursing students, which found that $14 \%$ of new graduates are looking for jobs, whereas $44 \%$ are working under non-extended, part-time work arrangements ${ }^{(30)}$.

\section{CONCLUSION}

This study points out that all forms of healthcare workforce management (public, outsourced to a Social Organization, and private) establish outsourcing processes and employment bond flexibility, reducing costs through dismantling of stable employment and, consequently, labor rights in both the public and private sectors. Nonetheless, in private sector management, it was possible to observe more solid application of outsourcing and lack of security, followed by outsourced management to Social Organizations, and finally by direct administration using the trick of temporary contracts.

Regarding labor relations and power in the workplace, researchers classify them as different at the three studied hospitals. From the aspects related to types of employment bond, it is possible to infer the instability under the CLT system and temporary contracts in the management of the workforce based on insecurity.

At private and outsourced hospitals, the power asymmetry between workers and management leads to despotism pervaded by personal and arbitrary relations. Workers' autonomy is higher in the public sector, founded upon stability provided by the statutory regime. Regarding other temporary workers, their condition is similar to the CLT system.

As in the private hospital case study, cooperatives were the attempt to apply the trend of dismantling stable employment for nursing professionals. Corporate contracting is the practice for graduate professionals such as speech pathologists, nutritionists, and psychologists. Regarding doctors and physiotherapists, corporate contracts occur through a subcontractor instead of the hospital. At the hospital run by a Social Organization, a CLT contract replaced the hiring of all public workers under the statutory regime. The public hospital used the trick of "eternal" temporary contracts.

Thus, it can be said that outsourcing and the dismantling of stable employment is the trend caused by capital's self-valuing movement and of post-Fordist work organizations, aggravated, though, by the intervention of the national state. This assumption was found in the survey conducted at the three hospitals located in the greater São Paulo area under public administration, outsourced administration to a Healthcare Social Organization (HSO), and private management. In this context, it is up to healthcare workers to build collective actions for improvements in their working conditions and services to the population, fighting austerity, insecurity, and work intensification policies.

\section{RESUMO}

Objetivo: Relacionar a estrutura organizativa dos hospitais como núcleo de uma rede de serviços subcontratados e a flexibilização dos vínculos contratuais dos profissionais de saúde no contexto de capitalismo financeirizado, analisando os regimes de trabalho condicionados centralmente pelo vínculo empregatício. Método: Pesquisa qualitativa através de etnografia, realização de entrevistas, análise de dados e utilização de estudo de caso. Os estudos de caso concentram-se em três hospitais localizados Região Metropolitana de São Paulo com gestões distintas: administração pública; administração terceirizada para Organização Social de Saúde (OSS); e administração privada Resultados: Destacamos a tendência da terceirização, do desmonte do emprego estável e a conformação de relações trabalhistas assimétricas para as profissões em saúde. Conclusão: Esses aspectos são característicos do período do capitalismo contemporâneo e da organização pós-fordista do trabalho. Nesse contexto, o subfinanciamento do Estado inviabiliza uma política de recursos humanos efetiva, configurando o ambiente propício para as terceirizações e flexibilidade do vínculo empregatício para os trabalhadores de saúde.

\section{DESCRITORES}

Capitalismo; Força de Trabalho; Emprego; Serviços Terceirizados; Pessoal de Saúde; Recursos Humanos em Hospital.

\section{RESUMEN}

Objetivo: Relacionar la estructura organizativa de los hospitales como núcleo de una red de servicios subcontratados y la flexibilización de vínculos contractuales de los profesionales sanitarios en el marco del capitalismo financierizado, analizando los regímenes laborales condicionados centralmente por el vínculo de empleo. Método: Investigación cualitativa mediante etnografía, realización de entrevistas, análisis de datos y utilización de estudio de caso. Los estudios de caso se concentran en tres hospitales ubicados en la Región Metropolitana de São Paulo con gestiones distintas: administración pública; administración tercerizada para Organización Social de Salud (OSS); y administración privada Resultados: Destacamos la tendencia de la tercerización, del desmonte del empleo estable y la conformación de relaciones laborales asimétricas para las profesiones sanitarias. Conclusión: Dichos aspectos son característicos del período del capitalismo contemporáneo y la organización post-fordista del trabajo. En ese marco, la subfinanciación del Estado inviabiliza una política de recursos humanos efectiva, configurando el ambiente propicio para las tercerizaciones y la flexibilidad del vínculo de empleo para los trabajadores de la salud.

\section{DESCRIPTORES}

Capitalismo; Fuerza de Trabajo; Empleo; Servicios Externos; Personal de Salud; Personal de Hospital.

\section{REFERENCES}

1. Donnangelo MC. Medicina e sociedade: o médico e seu mercado de trabalho. São Paulo: Pioneira; 1975.

2. Andreazzi MFS, Bravo MIS. Privatização da gestão e organizações sociais na atenção à saúde. Trab Educ Saúde. 2014;12(3):499-518. 
3. Carneiro CCG, Martins MIC. Novos modelos de gestão do trabalho no setor public de saúde e o trabalho do agente comunitário de saúde. Trab Educ Saúde. 2015;13(1):45-65.

4. Silva LIMC, Peduzzi M. Os recursos humanos de enfermagem da perspectiva da força de trabalho: análise da produção científica. Rev Esc Enferm USP. 2005;39(n.esp.):589-96.

5. Durand JP. A refundação do trabalho no fluxo tensionado.Tempo Soc. 2003;15(1):139-58.

6. Pierantoni CR. As reformas do Estado, da saúde e recursos humanos: limites e possibilidades. Ciênc Saúde Coletiva. 2001;6(2):341-60.

7. Lourenço EAS. Terceirização: a derruição de direitos e a destruição da saúde dos trabalhadores. Serv Soc Soc. 2015;(123):447-75.

8. Burawoy M. A Transformação dos regimes fabris no capitalismo avançado [Internet]. São Paulo; 1990 [citado 2015 ago. 15]. Disponível em: http://www.anpocs.org.br/portal/publicacoes/rbcs_00_13/rbcs13_02.htm9.

9. Nichols T, Cam S, Wen-chi GC, Soonok C, Wei Z, Tongqing F. Factory regimes and the dismantling of established labor in Asia: a review of cases from large manufacturing plants in China, South Korea and Taiwan [abstract]. Work Employ Soc. 2004;18(4):663-85.

10. Pessanha EGF, Artur K. Direitos trabalhistas e organização dos trabalhadores num contexto de mudanças no mundo do trabalho: efeitos sobre os trabalhadores da saúde. Ciênc Saúde Coletiva. 2013;18(6):1569-80.

11. Cordeiro L, Soares CB. Work process in Primary Health Care: action research with Community Health Workers. Ciênc Saúde Coletiva. 2015;20(11):3581-8.

12. Martins MIC, Molinaro A. Reestruturação produtiva e seu impacto nas relações de trabalho nos serviços públicos de saúde no Brasil. Ciênc Saúde Coletiva. 2013;18(6):1667-76.

13. Campos CMS, Viana N, Soares CB. Transformations in contemporaneous capitalism and its impact on state policies: the SUS in debate. Saúde Soc. 2015;24 Suppl 1:82-91.

14. Mendes A. Brazilian public health in the context of a State crisis or a crisis of capitalism? Saúde Soc. 2015;24 Suppl.1:63-78.

15. Mendes A. The long battle for SUS funding [editorial]. Saúde Soc. 2013;22(4):991-3.

16. Marx K. El capital: crítica de la economía política. México: Fondo de Cultura Económica; 1987. Libro III.

17. Mendes A. O fundo público e os impasses do financiamento da saúde universal brasileira. Saúde Soc. 2014;23(4):1183-97.

18. Burawoy M. the extended case method: four countries, four decades, four great transformations and one theoretical tradition. California: University of California Press; 2009.

19. Soares CB, Campos CMS, Yonekura T. Marxism as a theoretical and methodological framework in collective health: implications for systematic review and synthesis of evidence. Rev Esc Enferm USP. 2013;47(6):1403-9. DOI: http://dx.doi.org/10.1590/S0080623420130000600022

20. Guimarães CM, Carvalho JC. Terceirização em cuidados continuados: uma abordagem de gestão de risco. Ciênc Saúde Coletiva. 2012;17(5):1179-90.

21. Câmara mantém terceirização de todas as atividades. Folha de S. Paulo [Internet]. 2015 abr. 23 [citado 2015 ago. 12]; Mercado B5. Disponível em: http://www1.folha.uol.com.br/mercado/2015/04/1619938-camara-mantem-terceirizacao-de-todas-as-atividades-eestende-direitos-ao-setor-publico.shtml

22. Brasil. Lei n. 7.394, de 29 de outubro de 1985. Regula o exercício da profissão de Técnico em Radiologia, e dá outras providências [Internet]. Brasília; 1985 [citado 2014 fev. 26]. Disponível em: https://www.planalto.gov.br/ccivil_03/leis/l7394.htm

23. Zamberlan C, Siqueira HCH. A terceirização nos serviços e consequências no cuidar em enfermagem. Rev Bras Enferm. 2005;58(6):727-30.

24. Pina JA, Stoutz EN. Intensificação do trabalho e saúde do trabalhador: uma abordagem teórica. Rev Bras Saúde Ocup. 2014;39(130):150-60.

25. Oliveira RS, Morais HMM, Goes PSA, Botazzo C, Magalhães BG. Relações contratuais e perfil dos cirurgiões-dentistas em centros de especialidades odontológicas de baixo e alto desempenho no Brasil. Saúde Soc. 2015;24(3):792-802.

26. Baraldi S, Car M. Labor flexibilization and deregulation for nursing workers in Brazil: the profae case. Rev Latino Am Enfermagem. 2008;16(2):205-11.

27. Machado MH. Trabalho e emprego em saúde. In: Giovanella L, Escorel S, Lobatoo LVC, Noronha JC, Carvalho Al, organizadores. Políticas e sistemas de saúde no Brasil. $2^{\mathrm{a}}$ ed. Rio de Janeiro: Fiocruz; 2011. p. 309-30.

28. Martiniano R, Surdu S, Moore J; Center for Health Workforce Studies. Health care employment projections: an analysis of bureau of labor statistics settings and occupational projections, 2012-2022 [Internet]. Rensselaer; 2014 [cited 2015 Aug 12]. Available from: http://chws. albany.edu/archive/uploads/2014/08/blsproj2014.pdf

29. Tremblay $M$, Chênevert $D$, Hébert $A$. Le rôle des conditions de travail dans la satisfaction et la loyauté des infirmières d'agence au Québec. Relat Ind [Internet]. 2012 [cited 2015 Aug 12];67(3):477-504. Available from: http://www.erudit.org/revue/ri/2012/v67/n3/1012540ar.pdf

30. Fabregas B. Chômage infirmier et précarisation: la vérité par les chiffres... [Internet]. 2014 [cited 2015 Aug 12]. Available from: http://www. infirmiers.com/emploi/emploi/chomage-infirmier-et-precarisation-la-verite-par-les-chiffres.html 